\title{
Stimulation of testicular protein synthesis in vivo by gonadotrophins and growth hormone in hypophysectomized adult mice
}

\author{
N. R. Lawrence and A. G. Davies \\ Department of Physiology, Medical School, Birmingham B15 2TJ, U.K.
}

\begin{abstract}
Summary. The effects of FSH, HCG, GHand testosterone on testicular protein synthesis were investigated in hypophysectomized adult mice by measuring the incorporation of tritiated lysine into acid-precipitable material. The incorporation per mg protein was increased by FSH, HCG and GH but decreased by testosterone. The maximum effect of FSH occurred at between 8 and $14 \mathrm{~h}$ after administration of the hormone, much later than found in vitro for the rat.
\end{abstract}

\section{Introduction}

The administration of FSH in vivo stimulates the incorporation of amino acid into protein in the immature rodent testis in vitro (Means \& Hall, 1967) and in vivo (Davies, Davies \& Sumner, 1975). It has also been shown that FSH increases amino acid incorporation in vitro in testicular tissue from hypophysectomized adult rats (Means \& Hall, 1968). As the role of FSH in the control of normal testicular function in adult mammals has not yet been defined we felt it was important to find out whether FSH stimulates testicular amino acid incorporation in vivo as well as in vitro. Because other hormones are normally present in the testis, the effects of chorionic gonadotrophin, testosterone and growth hormone, alone and in combination with FSH, were also investigated.

\section{Materials and Methods}

Mice of the CFW strain were used. Groups of 10-16 mice born on the same day were fostered by pairs of lactating mothers. In each experiment the mice of most uniform body weight in one or more foster groups were used, and the details of the experiments are given in the 'Results'.

Hypophysectomy. Mice were hypophysectomized by the parapharyngeal route at between 60 and 80 days of age and were used for experiments 9-12 days later. All animals in a foster group were operated on at the same time. The sella turcica was examined at autopsy and animals with pituitary fragments were discarded. Control animals were given sham operations.

Hormones. Purified human pituitary FSH, extracted by the method of Butt \& Lynch (1974), contained 8000 i.u. FSH and 150 i.u. LH per mg. Human chorionic gonadotrophin (HCG) with an LH activity of 1500 i.u. and an FSH activity of $<15$ i.u. per $\mathrm{mg}$ was obtained from Paines and Byrne Ltd. Human pituitary growth hormone (GH) was extracted by the method of Raben (1959). These hormones were administered in $0.15 \mathrm{ml}$ saline. Testosterone phenylpropionate was given in $0.1 \mathrm{ml}$ arachis oil. Each mouse received a single s.c. injection of hormone or of vehicle $12 \mathrm{~h}$ before death.

Tritiated lysine. Two hours before beingkilled each mouse received a s.c. injection of $0.25 \mathrm{ml}$ saline containing $\mathrm{L}-\left[4,5-{ }^{3} \mathrm{H}\right]$ lysine monohydrochloride (sp. act. $250 \mathrm{mCi} / \mathrm{mmol}$ ). Doses ranging from $2 \cdot 5$ $\mu \mathrm{Ci}$ to $25 \mu \mathrm{Ci}$ were used in different experiments but within each experiment the same dose of isotope was given to each mouse.

Extraction procedure. Mice were killed at between 09.00 and 12.00 hours by cervical dislocation. After removal of the tunicae albugineae the testes were homogenized together in $2 \mathrm{ml}$ distilled water. The homogenate was mixed with $0.5 \mathrm{ml}$ cold $2.5 \mathrm{~N}$-perchloric acid and left at $4^{\circ} \mathrm{C}$ for $1 \mathrm{~h}$. The preci- 
pitate was then collected by centrifugation at $600 \mathrm{~g}$ for $2 \mathrm{~min}$, washed twice in $0.5 \mathrm{~N}$-perchloric acid, once in ethanol and once in ether, before being solubilized at $50-60^{\circ} \mathrm{C}$ in $1 \mathrm{ml}$ of a $2: 1(\mathrm{v} / \mathrm{v})$ mixture of $13 \%(\mathrm{w} / \mathrm{v})$ sodium hydroxide and methanol. After the extract had been neutralized with $0.5 \mathrm{ml}$ $4 \mathrm{M}$-nitric acid, the protein content was measured in duplicate $0.1 \mathrm{ml}$ aliquots by the method of Lowry, Rosebrough, Farr \& Randall (1951). For scintillation spectrometry duplicate $0.5 \mathrm{ml}$ aliquots were placed in $10 \mathrm{ml}$ quantities of toluene-based scintillation fluid containing PPO, POPOP, ethanol and Triton X-100. Protein and radioactivity measurements were also made on liver extracts from each mouse.

The incorporation of tritiated lysine into testicular protein was expressed as $\mathrm{d} / \mathrm{min}$ per $\mathrm{mg}$ protein. In each experiment the results were evaluated statisticaliy by analyses of variance.

\section{Results}

There was no significant effect of any of the hormonal treatments on the incorporation of lysine into liver protein.

\section{Effect of FSH at different times after hypophysectomy}

The effect of FSH on the incorporation of $\left[{ }^{3} \mathrm{H}\right]$ lysine into testicular protein was investigated at $1,2,3,7,14$ and 28 days after hypophysectomy and in a group of sham-operated mice. Of the total 116 mice used, half were treated with FSH and half received an injection of saline.

There was an increase in the incorporation of tritiated lysine into testicular protein in each group of hypophysectomized mice, the effect being most marked in mice hypophysectomized 28 days before killing (Table 1). The overall effect of FSH was significant $(P<0.001)$. Although the stimulatory effect of FSH appeared to decline from 1 to 14 days after hypophysectomy, there were no significant differences between any of these means. In the saline-treated animals the length of time between hypophysectomy and death did not affect lysine incorporation significantly.

Table 1. Effect of a single injection of 5 i.u. FSH on mean \pm S.E.M. incorporation of $\left[{ }^{3} \mathbf{H}\right]$ lysine into testicular protein $(\mathrm{d} / \mathrm{min} / \mathrm{mg}$ protein) in mice at different intervals after hypophysectomy

\begin{tabular}{llccccrc}
\hline & & \multicolumn{5}{c}{ Time after hypophysectomy (days) } \\
\cline { 2 - 7 } & $\begin{array}{c}\text { Intact } \\
\text { control }\end{array}$ & \multicolumn{1}{c}{1} & 2 & 3 & 7 & 14 & 28 \\
\hline FSH & $982 \pm 83$ & $1493 \pm 158$ & $1456 \pm 141$ & $1376 \pm 129$ & $1244 \pm 124$ & $1165 \pm 93$ & $1961 \pm 94$ \\
Saline & $844 \pm 60$ & $1095 \pm 98$ & $962 \pm 53$ & $1003 \pm 64$ & $799 \pm 88$ & $845 \pm 75$ & $899 \pm 49$ \\
\hline
\end{tabular}

\section{Time course of FSH effect}

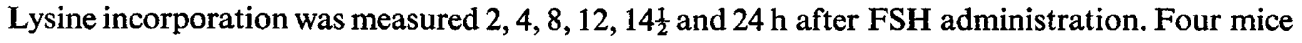
were used at each of these times.

Lysine incorporation (Table 2) was affected significantly by the length of time between FSH administration and death $(P<0.001)$, the maximum effect occurring at between 8 and $14 \frac{1}{2} \mathrm{~h}$ after FSH was given.

\section{Response to different doses of FSH}

Groups of four mice received injections of $0 \cdot 25,0 \cdot 75,2 \cdot 5,7 \cdot 5,22 \cdot 5$ and $67 \cdot 5$ i.u. of FSH.

Lysine incorporation was increased $38 \%$ by 0.25 i.u. FSH and $62 \%$ by 0.75 i.u. (Table 3 ). Over the range $0-0.75$ i.u., incorporation correlated with the dose of FSH $(r=0.92, P<0.001)$, but there was no significant difference in the effect of doses ranging from 0.75 i.u. to 67.5 i.u. 
Table 2. Mean \pm S.E.M. incorporation of $\left[{ }^{3} \mathrm{H}\right]$ lysine into testicular protein (d/min/mg protein) in mice at different times after a single injection of 5 i.u. FSH

\begin{tabular}{lcccccc}
\hline \multirow{2}{*}{$\begin{array}{l}\text { Saline } \\
\text { control }\end{array}$} & 2 & 4 & 8 & $14 \frac{1}{2}$ & 16 & 24 \\
\hline $1511 \pm 36$ & $1626 \pm 74$ & $1813 \pm 21$ & $2632 \pm 96$ & $2312 \pm 100$ & $1738 \pm 132$ & $1384 \pm 91$ \\
\hline
\end{tabular}

Table 3. Effect of different doses of FSH on mean \pm S.E.M. incorporation of $\left[{ }^{3} \mathrm{H}\right]$ lysine into testicular protein (d/min/mg protein) in mice

\begin{tabular}{lcccccc}
\hline \multirow{2}{*}{$\begin{array}{c}\text { Saline } \\
\text { control }\end{array}$} & 0.25 & 0.75 & 2.5 & 7.5 & $22 \cdot 5$ & 67.5 \\
\cline { 2 - 6 } & $10677 \pm 317$ & $12525 \pm 361$ & $11794 \pm 684$ & $11973 \pm 320$ & $12481 \pm 698$ & $13060 \pm 614$ \\
\hline $7759 \pm 205$ & 10677 &
\end{tabular}

\section{Effect of $H C G$, testosterone and $G H$}

To find out whether the effect of FSH was shared or modified by other hormones, FSH was given alone and in combination with HCG, testosterone or GH in three separate experiments (Table 4). The treatments were given to groups of 2-5 mice.

Separate administration of FSH and HCG resulted in increases in lysine incorporation of 34 and $43 \%$, respectively (Table 4 ). When the hormones were given together their effects were additive. A two-way analysis of variance showed that the main effect of each hormone was significant $(P<0.01)$.

Table 4. Effects of FSH, HCG, GH and testosterone (see text) on mean \pm S.E.M. incorporation of $\left[{ }^{3} \mathrm{H}\right]$ lysine into testicular protein $(\mathrm{d} / \mathrm{min} / \mathrm{mg}$ protein) of mice

\begin{tabular}{|c|c|c|c|}
\hline Saline & FSH (5 i.u.) & HCG (10 i.u.) & $\begin{array}{l}\text { FSH (5 i.u.) }+ \\
\text { HCG (10 i.u.) }\end{array}$ \\
\hline $1127 \pm 57$ & $1504 \pm 104$ & $1616 \pm 24$ & $2026 \pm 186$ \\
\hline Saline* & FSH $(5 \text { i.u. })^{*}$ & $\begin{array}{c}\text { Testosterone } \\
(1 \mathrm{mg}) \dagger\end{array}$ & $\begin{array}{l}\text { FSH (5 i.u.) }+ \\
\text { testosterone } \\
(1 \mathrm{mg}) \dagger\end{array}$ \\
\hline $1471 \pm 27$ & $1941 \pm 130$ & $1319 \pm 123$ & $1667 \pm 33$ \\
\hline Saline & FSH (0.5 i.u.) & $\mathrm{GH}(0 \cdot 1 \mathrm{mg})$ & $\begin{array}{c}\text { FSH }(0.5 \text { i.u. })+ \\
\text { GH }(0.1 \mathrm{mg})\end{array}$ \\
\hline $404 \pm 14$ & $488 \pm 23$ & $481 \pm 42$ & $591 \pm 34$ \\
\hline
\end{tabular}

* Plus arachis oil.

$\dagger$ Plus arachis oil and saline.

Testosterone decreased incorporation of lysine by $10 \%$, while FSH caused an increase of $32 \%$ The main effect of each hormone was statistically significant $(P<0.001$ for FSH, $P<0.05$ for testosterone), but their interaction was not.

Treatment with FSH and GH separately increased lysine incorporation by $21 \%$ and $19 \%$ and these effects were additive. The main effects were significant $(P<0.025)$. 


\section{Discussion}

FSH stimulated the incorporation of labelled lysine into testicular protein in vivo in hypophysectomized adult mice. Since none of the hormonal treatments affected lysine incorporation into liver protein, it is unlikely that treatment affected the size of the total pool of lysine in the body and the incorporation of labelled lysine appears to be a valid index of protein synthesis in the testis, though proof of this would require measurements of the pool. In intact mice FSH did not affect testicular incorporation of lysine significantly. This may have been because testicular binding sites in the intact mice were already saturated with endogenous FSH. However, FSH increases the production of cyclic AMP: this is destroyed by a phosphodiesterase which disappears from the testes after hypophysectomy (Christiansen \& Desautel, 1973). If the rate of protein synthesis is controlled by the concentration of CAMP, the presence of phosphodiesterase in the testes of intact animals would diminish the effect of FSH on lysine incorporation. Dibutyryl cyclic AMP stimulates leucine incorporation in Sertoli cells in culture (Dorrington, Roller \& Fritz, 1975) but we have been unable to stimulate testicular protein synthesis in vivo with dbcAMP (Davies et al., 1975).

A dose of 5 i.u. FSH was used in most of the experiments so as to obtain an effect that was on the plateau of the dose-response curve, the concentration of hormone in the blood almost certainly reached an artificially high level. However, the response was not thought to be unphysiological as 5 i.u. did not stimulate lysine incorporation very much more than did $0 \cdot 25$ i.u., a dose more probably in the physiological range. Though stimulation of protein synthesis appeared to start shortly after administration of FSH the peak effect occurred at about $12 \mathrm{~h}$. This time course is similar to that in the immature mouse testis in vivo (Davies et al., 1975) but differs markedly from that found in rat testicular tissue in vitro (Means \& Hall, 1967, 1968), for which a plateau was reached at between 1 and $2 \mathrm{~h}$. The longer latency occurring in vivo is due presumably to the time required for the hormone to pass from the site of injection to the testis and across the blood-testis barrier.

The action of HCG could not have been due to contaminating FSH activity because HCG further stimulated testicular lysine incorporation in the presence of a dose of FSH large enough to have the maximum effect that FSH was capable of producing alone. $\mathrm{LH}$ has been shown to stimulate protein synthesis in the adult rabbit testis in vitro (Hall \& Eik-Nes, 1962) though neither LH nor HCG has a significant effect on testicular protein synthesis in immature rats and mice (Means \& Hall, 1967; Davies et al., 1975). The effect of LH on steroidogenesis is secondary to its stimulatory action on testicular protein synthesis (Hall \& Eik-Nes, 1962) and HCG increases the activity of a number of enzymes involved in testicular steroidogenesis (Schoen \& Samuels, 1965; Hagerman, 1967; Shikita \& Hall, 1967). In contrast to HCG, testosterone reduced lysine incorporation into testicular protein in vivo, an effect which has also been demonstrated in vitro (Morris \& Davis, 1966). This suggests that testosterone may inhibit synthesis of steroidogenic enzymes in the testis. A large dose of testosterone was administered so as to ensure a high concentration of the hormone in the testicular interstitial fiuid where the level is normally many times greater than in the peripheral plasma (Eik-Nes, 1970).

In which type(s) of cell does FSH stimulate protein synthesis? Histological examination showed that there were very few spermatids in the testes of mice hypophysectomized 1 month before treatment with FSH. The high specific radioactivity in material from these animals suggests that FSH has relatively little effect on protein synthesis in spermatids. Recently it has been reported that FSH stimulates protein synthesis in rat Sertoli cells in culture (Dorrington et al., 1975). However, autoradiographs of sections of testes from hypophysectomized mice show that FSH stimulates lysine incorporation in the nuclei of germ cells, particularly the preleptotene and mid-pachytene spermatocytes, as well as in Sertoli nuclei (Davies \& Lawrence, 1976). FSH stimulates production of an androgen-binding protein by Sertoli cells (Hansson et al., 1973) but this effect diminishes as the time of administration after hypophysectomy increases (Hansson et al., 1974). The absence of such a decrease in our experiments suggests that androgen-binding protein formed no more than a small proportion of the protein synthesized under the influence of FSH. Furthermore, there are no major qualitative differences in the proteins from the testes of FSH-treated and control animals (Means, 1971), and FSH probably stimulates the synthesis of a range of proteins rather than a single protein. 
Supplies of FSH and GH were made available by the Medical Research Council. N.R.L. was in receipt of an M.R.C. Postgraduate Training Award.

\section{References}

BUTT, W.R. \& LYNCH, S.S. (1974) Techniques for the purification of human pituitary follicle stimulating hormone. Trans. Biochem. Soc. 2, 785-787.

Christiansen, R.O. \& Desautel, M. (1973) Induction of testicular cyclic nucleotide phosphodiesterase by LH and FSH. Endocrinology 92, A-100 (No. 104).

Davies, A.G. \& LAWRENCE, N.R. (1976) Stimulation of nuclear protein synthesis in testicular germinal and Sertoli cells by follicle-stimulating hormone. $J$. Physiol., Lond. 257, 18-19P.

Davies, A.G., Davies, W.E. \& Sumner, C. (1975) Stimulation of protein synthesis in vivo in immature mouse testis by FSH. J. Reprod. Fert. 42, 415-422.

DORRINGTON, J.H., ROLleR, N.F. \& FrITZ, I.B. (1975) Effects of FSH on rat Sertoli cells in culture: increase in cAMP and in incorporation of ${ }^{3} \mathrm{H}$-leucine. Moll. cell. Endocr. 3, 57-70.

EIK-NES, K.B. (1970) Synthesis and secretion of androstenedione and testosterone. In The Androgens of the Testis, pp. 10-14. Ed. K. B. Eik-Nes. Dekker, New York.

HAGRRMAN, D.D. (1967) Stimulation of rat testis microsomal 17a-hydroxyprogesterone side-chain cleavage enzyme by $\mathrm{LH}$ added in vitro. Biochem. J. 105, 1119-1127.

Hall, P.F. \& EIK-Nes, K.B. (1962) The action of gonadotrophic hormones upon rabbit testis in vitro. Biochim. biophys. Acta 63, 411-422.

Hansson, V., Reusch, E., Trygstad, O., Torgersen, O., Ritzén, E.M. \& French, F.S. (1973) FSH stimulation of testicular androgen binding protein. Nature, New Biol. 246, 56-58.
Hansson, V., Trygstad, O., French, F.S., Mclean, W.S., Smith, A.A., Tindall, D.J., Weddington, S.C., Petrusz, P., Nayfeh, S.N. \& Ritzén, E.M. (1974) Androgen transport and receptor mechanisms in testis and epididymis. Nature, Lond. 250, 387391.

Lowry, O.H., Rosebrough, N.J., FarR, A.L. \& RANDALL, R.J. (1951) Protein measurement with the Folin phenol reagent. J. biol. Chem. 193, 265-275.

Means, A.R. (1971) Concerning the mechanism of FSH action: rapid stimulation of testicular synthesis of nuclear RNA. Endocrinology 89, 981-989.

Means, A.R. \& Hall, P.F. (1967) Effect of FSH on protein biosynthesis in testes of the immature rat. Endocrinology 81, 1151-1160.

Means, A.R. \& Hall, P.F. (1968) Protein biosynthesis in the testis. I. Comparison between stimulation by FSH and glucose. Endocrinology 82, 597-602.

Morris, R.N. \& Davis, J.R. (1966) Effect of testosterone on the incorporation of $\mathrm{L}-\mathrm{lysine}-\mathrm{U}-{ }^{14} \mathrm{C}$ into protein of rat testis slices. Archs int. Pharmacodyn. 162, 432-436.

RABEN, M.S. (1959) Human growth hormone. Recent Prog. Horm. Res. 15, 71-105.

SCHOEN, E.J. \& SAmueLs, L.J. (1965) Testicular androgen biosynthesis following corticotropin and human chorionic gonadotrophin administration. Acta endocr., Copenh. 50, 365-378.

ShIKITA, M. \& HaLL, P.F. (1967) The action of human chorionic gonadotrophin in vivo upon microsomal enzymes of immature rat testis. Biochim. biophys. Acta 136, 484-497. 